\title{
Sapwood hydraulic recovery following thinning in lodgepole pine
}

\author{
Douglas Edward Boyd REID ${ }^{\mathrm{a}, \mathrm{b} *}$, Uldis SILINS ${ }^{\mathrm{a}}$, Victor James LIEFFERS ${ }^{\mathrm{a}}$ \\ ${ }^{a}$ Centre for Enhanced Forest Management, Department of Renewable Resources, University of Alberta, 7-51 General Services Building, \\ Edmonton, Alberta T6G 2H1 \\ ${ }^{\mathrm{b}}$ Current address: Centre for Northern Forest Ecosystem Research, Ontario Ministry of Natural Resources, 955 Oliver Rd., \\ Thunder Bay, Ontario P7B 5E1
}

(Received 18 March 2005; accepted 8 December 2005)

\begin{abstract}
Sapflow in lodgepole pine (Pinus contorta) was measured over the summer of 2002 to assess the impact of reduced sapwood permeability ( $k$ ) after thinning on tree water use. Lodgepole pine in recently thinned (RT), thinned five years prior (5T), and un-thinned (C) stands were instrumented with thermal dissipation sap flow sensors. Daily water use varied considerably $\left(10.8-0.04 \mathrm{~L} \mathrm{Day}^{-1}\right)$, but trees in the thinned areas used more water. Despite lower $k$ and leaf specific hydraulic capacity $\left(Q_{\mathrm{L}}\right)$ in both RT and 5T trees, leaf related sapflow rates $\left(Q_{1}\right)$ were generally higher than for C trees. RT trees appeared to experience water stress immediately following thinning in June, but by mid August maintained higher $Q_{1}$ and canopy stomatal conductance than both 5T and $\mathrm{C}$ trees. Allocation to radial growth following thinning appears to maintain sufficient sapwood area, and may offset damage to conducting tissues enabling lodgepole pine trees to tolerate periodic water stress.
\end{abstract}

sapflow / hydraulic capacity / transpiration / thinning / lodgepole pine

Résumé - Rétablissement hydraulique de l'aubier suivant une éclaircie chez Pinus contorta. Le flux de sève a été mesuré chez Pinus contorta pendant l'été 2002 afin d'estimer l'impact de la réduction de perméabilité des tissus de l'aubier $(k)$ sur l'utilisation de l'eau par l'arbre après éclaircie. Des détecteurs de dissipation thermique destinés à mesurer le flux de sève ont été installés sur plusieurs arbres dans différentes parcelles : récemment éclaircie (RT), éclaircie depuis 5 ans $(\mathrm{T})$ et parcelle témoin non éclaircie $(\mathrm{C})$. La consommation quotidienne d'eau varie considérablement $(10,8$ à $0,04 \mathrm{~L}$ par jour), mais les arbres des peuplements éclaircis consomment davantage d'eau que les arbres témoins. Malgré une baisse de $k$ et de la capacité hydraulique foliaire spécifique $(Q L)$, le taux foliaire du flux de sève $(Q l)$ était généralement plus élevé pour RT et T que pour $\mathrm{C}$. Les arbres du traitement RT ont semblé subir un stress hydrique immédiatement après l'éclaircie en juin, mais à la mi-août ils ont gardé un $Q l$ et une conductance stomatique plus élevés que les arbres des traitements $5 \mathrm{~T}$ et $\mathrm{C}$. La croissance radiale après éclaircie semble maintenir une surface d'aubier suffisante et compenser les dommages causés à l'aubier et permettre aux arbres de tolérer des stress hydriques périodiques.

flux de sève / capacité hydraulique / transpiration / éclaircie / Pinus contorta

\section{INTRODUCTION}

Following wildfire, lodgepole pine is known to establish at very high densities that can result in intense intra-specific competition and reduced growth rates for individual trees and entire stands [14]. Thinning is a management strategy to increase the available growing space for retained trees, and is widely employed to improve growth rates in managed forests [4]. Trees retained after thinning may experience improved water relations because of reduced competition for water [5]. Conversely, water stress might increase following thinning [15] because of increased illumination of crowns stimulating stomatal opening [21] and greater wind loading [35] increasing atmospheric moisture demand. Declines in sapwood permeability following thinning [20] may also limit the ability of residual trees to take advantage of reduced competition after thinning. In many cases improved growth rates are not observed for several years following thinning [47, 48], particu-

*Corresponding author: Doug.Reid@mnr.gov.on.ca larly in fire origin lodgepole pine stands $[8,46]$. This delay in growth response remains poorly understood.

This study continues the efforts of a recent study on the effects of thinning on stem hydraulic properties of fire origin lodgepole pine trees, by Liu et al. [20]. They observed reduced height growth and sapwood permeability $(k)$, but greater leaf area four growing seasons after thinning relative to un-thinned control trees. The reduced $k$ of residual trees was offset by increased sapwood area and hydraulic capacity $\left(Q_{\mathrm{h}}\right)$ of the xylem, apparently from the newly deposited rings of sapwood. Reduction in both $k$ and conducting sapwood area (determined from staining) nevertheless suggest that thinning high-density lodgepole pine stands can result in damage to the water conducting sapwood tissues. The short- and long-term effects of thinning on transpiration and stomatal conductance associated with these changes in stem hydraulics remain unclear since changes in whole tree water use following thinning in lodgepole pine have not been reported.

Thermal dissipation sap flow techniques $[11,12]$ can be effectively used to measure water use of individual trees on 
a continuous basis, and have been used to study changes in tree water use following thinning $[3,18,25,28]$. When appropriate climatic data are collected concurrently with sap flow data, these techniques can provide powerful insights into atmospheric-biological controls of whole tree water use [43].

The objective of this study was to test the hypothesis that damage causing reduced stem sapwood permeability following thinning of dense stands [20] can result in impaired water supply to foliage. To do this, we revisited one of the stands used in the study of Liu et al. [20], and measured tree water use in thinned and un-thinned trees. The model proposed by Jarvis [15] suggests that we should expect increased sap flow rates and water use by trees retained following thinning, as well as greater water stress due to exposure to light and wind. Based on apparent damage to xylem from staining and reduced permeability associated with thinning [20], we anticipated that damage to sapwood might exacerbate water stress experienced by recently thinned trees resulting in stomatal closure. Because trees retained following thinning in 1998 had almost double the leaf area and lower leaf specific hydraulic capacity compared to adjacent controls [20], we suspected that following thinning, residual trees would experience reduced transpiration per unit leaf area relative to un-thinned controls.

\section{MATERIALS AND METHODS}

The experiment was conducted in an even-aged lodgepole pine stand $6 \mathrm{~km}$ south of Swan Hills, Alberta $\left(54^{\circ} 45^{\prime} \mathrm{N}, 115^{\circ} 45^{\prime} \mathrm{W}\right.$, $1260 \mathrm{~m}$ elevation). The stand established naturally following wildfire in 1978, and the site was classified as a bilberry/arnica - lodgepole pine ecosite, characteristic of the Upper Foothills natural region [39]. Based upon 15-year weather records from the two closest weather stations [9], mean annual precipitation is $440 \mathrm{~mm}$, and mean annual temperature is $3{ }^{\circ} \mathrm{C}$.

Liu et. al [20] established a $30 \times 30 \mathrm{~m}$ thinning treatment plot on a moderate $(<10 \%)$ south facing slope in the spring of 1998 . Thinning treatment removed the smaller trees in the stand resulting in an overstory density of 2800 stems/ha. Thinning slash was left on site, and though sapling sized ( $>1.3 \mathrm{~m}$ tall) black spruce (Picea mariana) were removed during treatment, a significant understory (42 654 stem/ha, 30-50 cm tall) had developed naturally by 2002 . We established another thinning treatment plot and a control (C) plot in May 2002. The treatment plots are identified as 5-year thinned (5T) and recently thinned (RT), respectively. The RT and C plots were established immediately east of the 5T plot. The RT and $\mathrm{C}$ plots were both $15 \times 30 \mathrm{~m}$ in size, and the $\mathrm{C}$ plot was established immediately north of the RT plot. The stand in the $\mathrm{C}$ plot consisted of dense lodgepole pine (28 383 stems/ha) with a healthy understory of black spruce (18 $038 \mathrm{stems} / \mathrm{ha}$ ). The density of lodgepole pine in the RT plot was reduced from 24271 to 2733 stems/ha. Thinning slash was left onsite, and understory spruce $<1.3 \mathrm{~m}$ in height (20 $292 \mathrm{stems} / \mathrm{ha}$ ) were retained. Measurements were made on 5T trees $(n=11)$, RT trees $(n=11)$, and $\mathrm{C}$ trees $(n=10)$ located throughout the central portion of the established plots.

\subsection{Whole-tree water use}

Whole-tree water use was measured using thermal dissipation sap flow sensors after the design of Granier $[11,12]$. This design utilizes the rate of heat dissipation by convection (water movement in sapwood) as the basic measurement principle for estimating sap flow velocity. Fine wire thermocouples within the probes measure changes in convective heat transport to determine sap flow velocity independent of conductive heat transport within the solid matrix of the sapwood.

\subsection{Sap flow sensor construction and installation}

Sap flow sensors consisted of a pair of fine-wire copper-constantan thermocouples connected at the constantan leads, allowing the measurement of temperature difference $(\Delta T)$ from the voltage difference between the two copper leads. The two thermocouples were installed at the midpoint of $1.5 \mathrm{~mm}$-diameter stainless steel needles, and inserted into aluminum tubes as described by Phillips et al. [31]. Each probe was $2.5 \mathrm{~mm}$ in diameter and $250 \mathrm{~mm}$ long. One of each thermocouple pair contained a fine wire constantan heater coil, which was installed in the upper position in the sapwood. Power to the heater coil was regulated to supply $200 \mathrm{~mW}$ from a $12 \mathrm{~V}$ DC source constructed and tested in the laboratory. The power dissipates as heat into the sapwood and the vertical sap flux surrounding the probe. The temperature difference between the heated upper probe and unheated lower probe can be used to measure changes in vertical sap flow $[12,17]$. When vertical sap flow is minimal, heat dissipation is governed by conduction. When vertical sap flow is high, the applied heat is dissipated more rapidly due to convection and the $\Delta T$ between the CT pair will decline. The amount of heat produced by the upper probe is a function of the regulated electric current, and the electronic resistance of the heater coil. Electronic resistance $(\Omega \mathrm{ohms})$ of the heater coils and thermocouple pairs was monitored throughout the experiment to ensure stability of all components. Any change in $\Omega$ was interpreted as damage to the instrument, and they were promptly repaired or replaced.

During periods of zero sap flux, typically after several hours of darkness, a stable maximum temperature difference $\left(\Delta T_{\max }\right)$ is observed, which can be used to evaluate subsequent changes in velocity [12]. Mean sap velocity on a sapwood area basis $\left(v_{\mathrm{s}}, \mathrm{m} \mathrm{s}^{-1}\right.$; [7]) along a radius can be estimated after Granier [12] as:

$$
\left.v_{s}=119 \times 10^{-6}\left[\Delta T_{\max }-\Delta T\right) / \Delta T\right]^{1.231}
$$

Subsequent sap flow measurements were made every $10 \mathrm{~min}$ for $1.5 \mathrm{~h}$ on two stem samples transported from the field and installed into a hanging water column permeameter in the lab connected to a bladder tank that could provide pressurized degassed and filtered water. Flow was initiated under a constant hydraulic head of $34 \mathrm{kPa}$ and run for $30 \mathrm{~min}$. The water source was then switched to the bladder tank (set at $172 \mathrm{kPa}$ ) for $30 \mathrm{~min}$, and subsequently switched back to the hanging water column $(34 \mathrm{kPa})$ for the final $30 \mathrm{~min}$. Total volume flow from the balance was $837.2 \mathrm{~cm}^{3}$ and $745.7 \mathrm{~cm}^{3}$, compared to the $851.1 \mathrm{~cm}^{3}$ and $736.3 \mathrm{~cm}^{3}$ calculated from Equation (1).

Sensors were installed in the outer $2 \mathrm{~cm}$ of sapwood at $1.0 \mathrm{~m}$ height, separated $10 \mathrm{~cm}$ vertically. Sensors were inserted radially into the sapwood on the north azimuth and protected from solar heating with reflective thermal insulation. Further correction for vertical temperature gradients resulting from solar heating of instrumented tree stems was made using non-heated sensors similarly installed into one tree in the 5T plot and one tree in the C plot. Between June 22 and August 30, 2002, $v_{\mathrm{s}}$ was measured in treated and control trees every $30 \mathrm{~s}$ to calculate and store 10-min averages using a CR10X (Campbell Scientific). The daily maximum $\Delta T$ was used as $\Delta T_{\max }$ for each 24-h period. 
A "roving sensor" method was used $[37,42]$ wherein one reference tree was monitored continuously within each treatment with two CT pairs (the second on the south side of the stem). Six other trees in each treatment were simultaneously monitored for portions of the study period with a single CT pair. There were no significant differences between north and south $v_{\mathrm{s}}$ in any of the reference trees. Over 2 3 day periods highly significant $\left(r^{2}=0.87-0.98\right)$ linear correlations between reference tree $v_{\mathrm{s}}$ and roving tree $v_{\mathrm{s}}$ were used to estimate roving tree $v_{\mathrm{s}}$ during periods where the tree was not instrumented.

Stem sapwood cross-sectional area $\left(\mathrm{m}^{2}\right)$ was measured from disks cut from the boles at the probe locations after final harvest using a desktop scanner. Most sensors were not in contact with heartwood, though some appeared to be just touching the sapwood/heartwood boundary. Average sapwood depth, based on measured sapwood area and assuming circular sapwood and basal area, was $2.3 \mathrm{~cm}$ in $5 \mathrm{~T}$ trees and $1.9 \mathrm{~cm}$ in RT and C trees. Subsequent to probe installation, we estimated that basal area growth added $<6 \%$ new sapwood area to the stem. All sampled trees were dominants that had been selected for retention in thinning, or were taller than all immediate neighbors in the control stand. Radial variation in sapflow is the least pronounced in dominant lodgepole pine trees [32], and we assumed that the sensors integrated any variation across the $2 \mathrm{~cm}$ radius they were in contact with. Whole tree sap flow $\left(Q, \mathrm{~m}^{3} \mathrm{~s}^{-1} ;[7]\right)$ was estimated from $v_{\mathrm{s}}$ by multiplying by sapwood area. Daily water use $\left(Q_{\mathrm{d}}, \mathrm{m}^{3} \mathrm{day}^{-1}\right)$ was calculated from $\Delta T$ data collected every 10 min over the measurement period, as was transpiration per unit leaf area $\left(Q_{1}\right.$; a.k.a. leaf-related sap flow [7]) from measured whole tree leaf area $\left(A_{1}, \mathrm{~m}^{2}\right)$. To facilitate comparison with other published transpiration data, $Q_{1}$ data were converted to molar units $\left(\mathrm{mmol} \mathrm{m} \mathrm{m}^{-2} \mathrm{~s}^{-1}\right)$. Mean mid-day $Q_{1}(\mathrm{mmol}$ $\mathrm{m}^{-2} \mathrm{~s}^{-1}$ ) was calculated from data collected between 11:00-14:00 MDT during each day of the measurement period.

\subsection{Tree measurements}

All instrumented trees were harvested in September 2002, prior to annual needle senescence. Tree height, diameter at breast height $(1.3 \mathrm{~m})$, live crown length, and the length of the terminal leader were recorded. Leaf area of each tree was estimated by collecting the entire crown. Differences in branch morphology and specific weight of needles between crown positions were accounted for by dividing crowns into upper, mid and lower sections. All crown samples were transported to the lab in plastic bags and stored overnight in the dark at $5{ }^{\circ} \mathrm{C}$. Sub-samples of fresh needles were taken from each section of each crown, and scanned. One-sided projected leaf area $\left(A_{\mathrm{L}} ; \mathrm{m}^{2}\right)$ of a sub-sample of needles from each crown section was measured with Sigma Scan-Pro ${ }^{\circledR}$ image analysis software. All scanned needles were dried to constant weight at $78{ }^{\circ} \mathrm{C}$ to determine needle specific area $\left(\mathrm{m}^{2} \mathrm{~g}^{-1}\right)$. Total $A_{\mathrm{L}}$ of each crown section was calculated from dry weight $(\mathrm{g})$ of all needles from that section. Crown section leaf areas were summed to determine total tree $A_{\mathrm{L}}$.

\subsection{Xylem hydraulic measurements}

Stem sections $\sim 1 \mathrm{~m}$ long from the base of the live crown on each instrumented tree were collected at the time of harvesting, stored in sealed plastic bags and placed in an insulated cooler and covered with ice cubes for transport to the laboratory. In the laboratory, $\sim 15 \mathrm{~cm}$ long stem sapwood sections, sub-sampled from the central portion of each stem segment were used to measure permeability $\left(k, \mathrm{~m}^{2}\right)$ using a hanging water column permeameter [32]. The permeameter consisted of a supply reservoir fitted with a bubble tube to maintain a constant hydraulic head, flexible plastic tubing and brass fittings connected to plastic and rubber caps that fit on either end of the sample, and a fixed outflow position that drained into a covered pan on an electronic scale. The reservoir was filled with filtered $(0.2 \mu \mathrm{m})$, degassed water that was stored in a $4 \mathrm{dm}^{3}$ flask and used within $24 \mathrm{~h}$ of degassing. The flow rate through the sample $\left(Q, \mathrm{~m}^{3} \mathrm{~s}^{-1}\right)$ was determined from the scale weight recorded every $30 \mathrm{~s}$, and used to calculate $k$ using Darcy's law:

$$
k=\frac{Q}{A_{\mathrm{s}}} \frac{L}{\Delta \Psi} \eta
$$

where $L$ is the sample length ( $\mathrm{m}$; measured on 4 sides and the average taken), $A_{s}$ is the sapwood area $\left(\mathrm{m}^{2}\right), \Delta \Psi$ is the water potential difference across the sample ( $\mathrm{Pa})$ and $\eta$ is water viscosity (Pa s). We calculated $\Delta \Psi$ from the product of head (the height difference between the bottom of the reservoir bubble tube and the fixed outflow position) acceleration due to gravity, and the density of water. The temperature of the outflow was measured and used to determine the density and viscosity of water from tables. Sub-samples used for measurement of $k$ were positioned as close as possible to the base of the live crown, above the location where probes were installed. From $k$, we also calculated hydraulic capacity $\left(Q_{\mathrm{h}}=k / \eta \times A_{\mathrm{s}}, \mathrm{m}^{4} \mathrm{~Pa}^{-1} \mathrm{~s}^{-1}\right)$, and leaf specific hydraulic capacity $\left(Q_{\mathrm{L}}=Q_{\mathrm{h}} / A_{\mathrm{L}} ; \mathrm{m}^{2} \mathrm{~Pa}^{-1} \mathrm{~s}^{-1}\right)$ [33] for each instrumented tree. It is important to note that $Q_{\mathrm{L}}$ and $Q_{1}\left(\mathrm{mmol} \mathrm{m}^{-2}\right.$ $\mathrm{s}^{-1}$ ) do not describe the same parameter, though both are divided by leaf area distal to the point of measurement. The former is determined from the bulk flow of water through a sampled section under a known stable hydraulic gradient. The latter is estimated from a point measurement of sap velocity in situ integrated across the entire sapwood cross sectional area, under a dynamic hydraulic gradient of unknown magnitude.

\subsection{Meteorological measurements}

Concurrent with sap flow measurements, meteorological measurements were collected every $30 \mathrm{~s}$, and 10-min averages recorded on a weather station positioned at the common corner of all three treatment plots. Relative humidity and air temperature $\left(T_{\mathrm{a}}\right)$, were measured on site using an HMP-45 relative humidity probe (Viasala, Finland) shielded against direct radiation, and used to calculate saturation vapour pressure $\left(e_{\mathrm{s}}, \mathrm{kPa}\right)$ and ambient vapour pressure $\left(e_{\mathrm{a}}, \mathrm{kPa}\right)$. Incident shortwave radiation above the canopy was measured using a pyranometer (SKYE SKS 1110), and net radiation $\left(Q^{*}, \mathrm{~W} \mathrm{~m} \mathrm{~m}^{-2}\right)$ was estimated based on shortwave radiation according to Linacre [19] assuming an albedo of 0.1, typical for pine forest [38]. Wind speed $\left(u ; \mathrm{m} \mathrm{s}^{-1}\right)$ was measured at $3.1 \mathrm{~m}$ using a 3-cup anemometer (RM Young, USA). Atmospheric moisture demand, or potential evaporation $\left(E_{0}, \mathrm{~mm} \mathrm{day}^{-1}\right)$, was estimated using the original Penman-combination equation [10]:

$$
E_{o}=\frac{(\Gamma \Pi)+\gamma((0.263+0.138 u) D)}{(\Gamma+\gamma)}
$$

where $\Gamma$ is the slope of the saturation vapour pressure vs. temperature curve $\left(\mathrm{kPa} \mathrm{K}^{-1}\right), \Pi$ is net radiation $\left(Q^{*}\right)$ expressed as an equivalent water depth $\left(\Pi\left(\mathrm{mm} \mathrm{day}^{-1}\right)=0.0353 Q^{*}\left(\mathrm{~W} \mathrm{~m}^{-2}\right)[10]\right), \gamma$ is the psychrometric constant $\left(0.067 \mathrm{kPa} \mathrm{K}^{-1}\right)$, and $D$ is the vapour pressure deficit of the air $\left(e_{\mathrm{s}}-e_{\mathrm{a}} ; \mathrm{kPa}\right)$. This approach combines 
the atmospheric effects of wind, radiation, and momentum to predict the rate of evaporation of water from a surface with unlimited supply [6]. We augmented our site meteorological data with cumulative precipitation data collected twice daily (morning and afternoon) at a nearby fire tower. When on-site for consecutive days, we also measured overnight precipitation using a simple rain gauge.

Evaporation from a vegetated surface does not occur at the same rate as open pan evaporation because stomatal behavior reduces canopy conductance in response to water stress. Monteith [27] showed that by including the relationship between canopy conductance and atmospheric conductance in a Penman type equation, evaporation from a vegetated surface can be more reasonably quantified. For aerodynamically rough pine forests or plantations, atmospheric conductance is generally very large in relation to canopy conductance, typically resulting in values associated with wind and vapour pressure deficit (i.e. $\gamma((0.263+0.138 u) \quad D)$ in Eq. (3)) up to 20 times

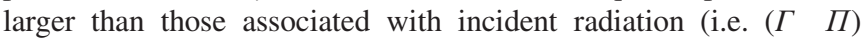
in Eq. (3)), allowing simplification of the Penman-Monteith equation [45]. Whole tree canopy stomatal conductance $\left(G_{\mathrm{c}} \mathrm{mm} \mathrm{s}^{-1}\right)$ was estimated from $Q_{1}\left(\mathrm{~m}^{3} \mathrm{~s}^{-1} \mathrm{~m}^{-2}\right)$ and an inversion of the simplified Penman-Monteith equation [23,45]:

$$
G_{\mathrm{c}}=\gamma \lambda Q_{\mathrm{l}} / \rho_{\mathrm{a}} c_{\mathrm{a}} D
$$

where $\lambda$ is the latent heat of vaporization of water $\left(\mathrm{MJ} \mathrm{kg}^{-1}\right.$; estimated from $\left.T_{\mathrm{a}}\right), \rho_{\mathrm{a}}$ is the density of air $\left(\mathrm{kg} \mathrm{m}^{-3}\right)$, and $c_{\mathrm{a}}$ is the heat capacity of air $\left(1.0 \times 10^{-3} \mathrm{MJ} \mathrm{kg}^{-1} \mathrm{~K}^{-1}\right)$. Periods where $D$ was less than $0.1 \mathrm{kPa}$ were not considered since there is a tendency to overestimate values of $G_{\mathrm{c}}$ determined using Equation 4 at low vapour pressure deficits [30].

\subsection{Analysis}

Because our treatment plots were not replicated, we limit our analysis to qualitative description of the temporal changes in $Q_{\mathrm{d}}, Q_{\mathrm{l}}$ and $G_{\mathrm{c}}$. Differences in tree characteristics between treatments were compared using one-way ANOVA. Post hoc comparisons were made using the LSD test in SAS (v. 8.0), and are reported as significant at the 0.05 level.

\section{RESULTS}

Meteorological conditions varied considerably, typical of sub-alpine environments in Alberta during the summer. Mean mid-day (11:00-14:50) values are presented for atmospheric variables (Fig. 1) to provide an indication of conditions during the period when peak daily $v_{\mathrm{s}}$ was observed, and when $Q_{1}$ and $G_{\mathrm{c}}$ data presented in Figure 3 were collected. The summer of 2002 was generally very warm with mean mid-day $T_{\mathrm{a}}$ of $17.8^{\circ} \mathrm{C}\left(28-5.4{ }^{\circ} \mathrm{C}\right)$. The low temperatures and precipitation recorded between July 31 st and August 5 th were due to a major low pressure system, during which $T_{\mathrm{a}}$ dropped as low as $-0.6{ }^{\circ} \mathrm{C}$ and precipitation recorded at the fire tower included $0.4 \mathrm{~cm}$ of snow between August 1st and 2nd. The measurement period was nevertheless dominated by sunny days with mid-day $Q^{*}$ averaging $485.8 \mathrm{~W} \mathrm{~m}^{-2}\left(718-135 \mathrm{~W} \mathrm{~m}^{-2}\right)$, interspersed with infrequent cloudy days (Fig. 2b). Variation in mid-day $D$ generally mirrored that of $Q^{*}$ (Fig. 2b), and averaged $1.7 \mathrm{kPa}(2.9-0.07 \mathrm{kPa})$. These variables, along with wind data contributed to the variation in $E_{\mathrm{o}}$ observed, which averaged $0.71 \mathrm{~mm} \mathrm{~h}^{-1}\left(1.06-0.20 \mathrm{~mm} \mathrm{~h}^{-1}\right)$ during the mid-day period presented (Fig. 2a). Rainfall recorded from May to August was $203.5 \mathrm{~mm}$ (57.5\% of normal), and total $E_{\mathrm{o}}$ over the course of the measurement period was $452 \mathrm{~mm}$.

Mean apparent sap velocity on a sapwood area basis $\left(v_{\mathrm{s}}\right)$ typically increased quickly after sunrise, reaching a maximum in the late morning. This was followed by a relatively stable period during mid-day, and a steep decline to very low flows at night (Fig. 2). Drastic mid-day depressions in $v_{\mathrm{s}}$ (e.g. July 14, Julian day 195, Fig. 2) were sometimes observed associated with changes in $Q^{*}$ and $D$, presumably due to a period of cloud cover. Less dramatic declines were typically observed on hot dry days during mid-day periods (e.g. July 15, DOY 196, Fig. 2). Zero flows ( $\left.\Delta T_{\max }\right)$ were generally observed during predawn hours when $D$ was at a minimum, and stomatal opening was not yet stimulated by incident solar radiation. In general there was a strong covariance between $v_{\mathrm{s}}$ and the atmospheric drivers of evaporation, indicating that $v_{\mathrm{s}}$ was primarily driven by the variation in atmospheric conditions experienced in all three treatments.

On hot dry days with full sunlight, the highest $v_{\mathrm{s}}$ for a given tree during each day was typically observed prior to peak values of $Q^{*} D$ and $E_{\mathrm{o}}$ (Fig. 2, Julian days 196-198). Plots of mean transpiration per unit of leaf area $\left(Q_{1}\right)$ versus $E_{0}$, by treatment during periods of high irradiance and $D$ typically resulted in asymptotic curves (Fig. 3). The data presented in Figure 3 are taken from $1 \mathrm{~h}$ before sunrise, till one hour after solar noon thereby avoiding the natural hysteresis typically observed for sap flow in trees. On most days, $Q_{1}$ increased rapidly at dawn, and tended to flatten out as $E_{\mathrm{o}}$ continued to increase in the early afternoon (Fig. 3, top row, July 15-17). For a few days, however, there appeared to be a lag between $Q_{1}$ and evaporative demand $E_{\mathrm{o}}$ (Fig. 3 bottom row). The meteorological data indicated that on these mornings, conditions were below the dew point.

There were large differences in daily water use of trees $\left(Q_{\mathrm{d}}\right)$ between treatments (Fig. 4a). Average $Q_{\mathrm{d}}$ over the summer of 2002 was $2.7 \mathrm{~L}$ for $5 \mathrm{~T}$ trees, $1.9 \mathrm{~L}$ for RT trees and $1.3 \mathrm{~L}$ for $\mathrm{C}$ trees. Individual trees transpired as much as $10.8 \mathrm{~L}$ (5T tree on July 10th, and as little as $0.04 \mathrm{~L}$ (C tree on August 2nd) in a single day. At the beginning of the measurement period, $Q_{\mathrm{d}}$ of 5T trees was nearly double that of both the RT and C trees (Fig. 4a). By the second week of August, however, $Q_{\mathrm{d}}$ of RT trees was similar to that of the $5 \mathrm{~T}$ trees, and about twice that of the $\mathrm{C}$ trees.

We also observed apparent differences in transpiration per unit leaf area $\left(Q_{1}\right)$ between treatments during the measurement period (Fig. 4b). From June 22nd until July 5th, mid-day $Q_{1}$ of the $5 \mathrm{~T}$ trees was higher than either the RT or $\mathrm{C}$ trees. Through the remainder of July, mid-day $Q_{1}$ did not differ between treatments. Following the cool wet period in early August, mean mid-day $Q_{1}$ of RT trees seemed to be consistently higher than that of both $\mathrm{C}$ trees and 5T trees. Similarly, canopy stomatal conductance $\left(G_{\mathrm{c}}\right)$ tended to be highest for $5 \mathrm{~T}$ trees in late June, but from August 16th (DOY 229) on was highest in RT 


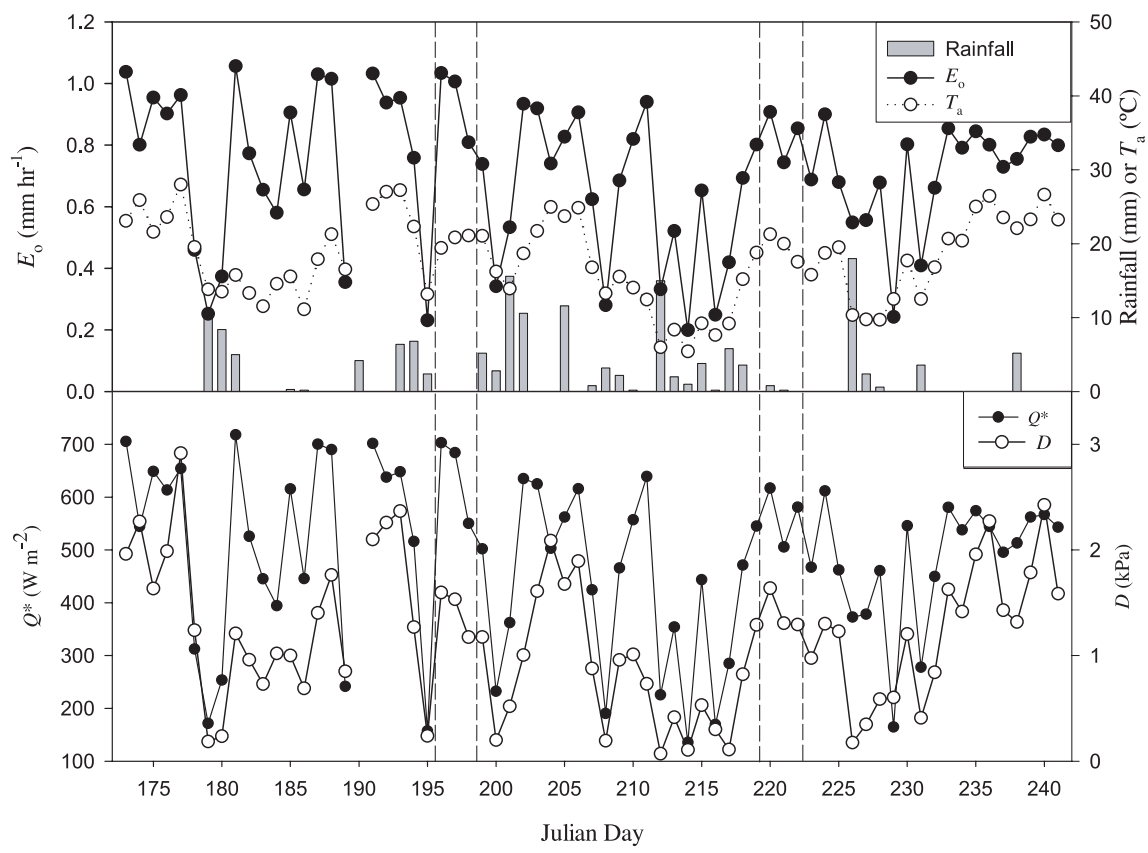

Figure 1. Mean midday potential evapotranspiration $\left(E_{o}\right)$, air temperature $\left(T_{a}\right)$, net radiation $\left(Q^{*}\right)$ and air vapour pressure deficit $(D)$ recorded at the study site. Shaded bars denote cumulative precipitation $(\mathrm{mm})$ for each day recorded at the Swan Hills fire-lookout approximately $10 \mathrm{~km}$ from the site.

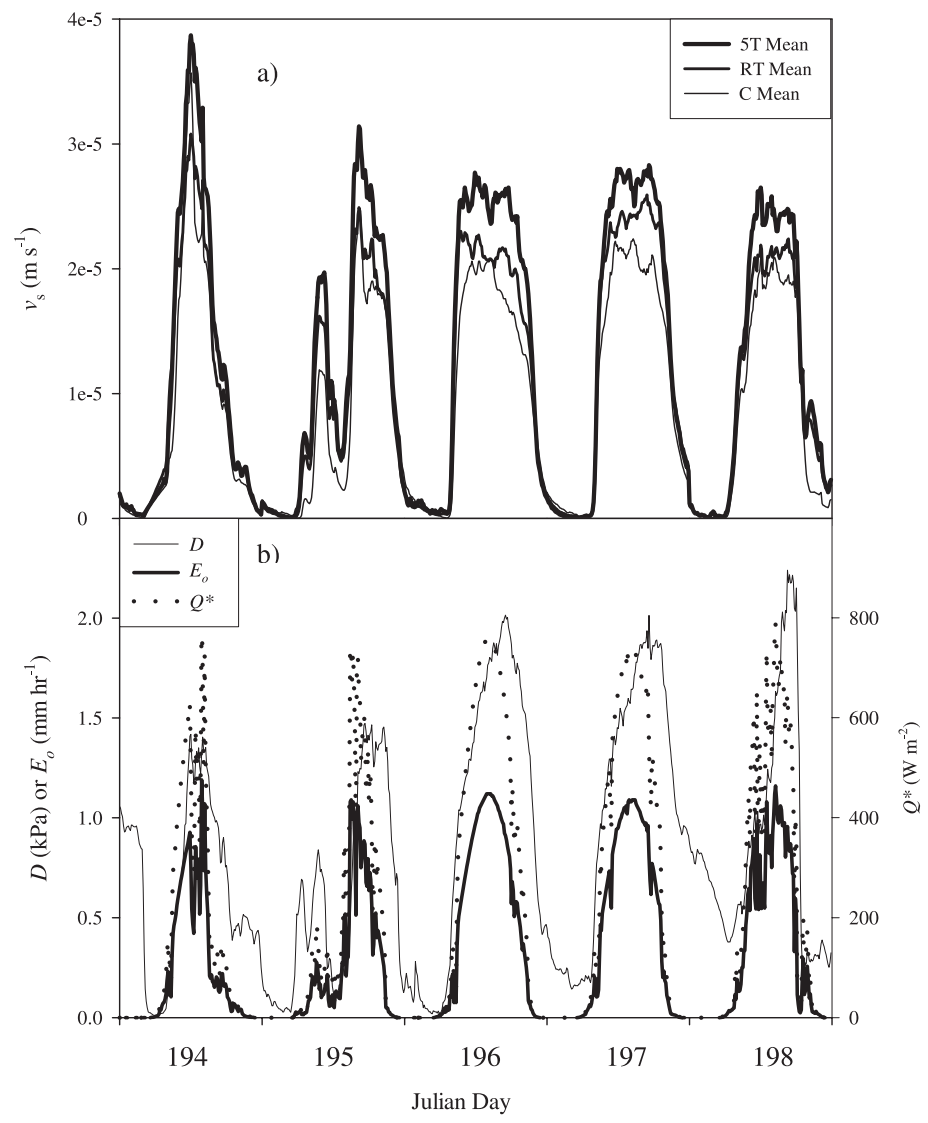

Figure 2. Typical 5-day pattern of (a) mean sap velocity on a sapwood area basis $\left(v_{\mathrm{s}}\right)$ for trees thinned in 1998 (5T), trees thinned in 2002 (RT) and unthinned controls $(\mathrm{C})$, and $(\mathrm{b})$ concurrent changes in vapour pressure deficit $(D)$, potential evaporation $\left(E_{\mathrm{o}}\right)$, and net radiation $\left(Q^{*}\right)$. 


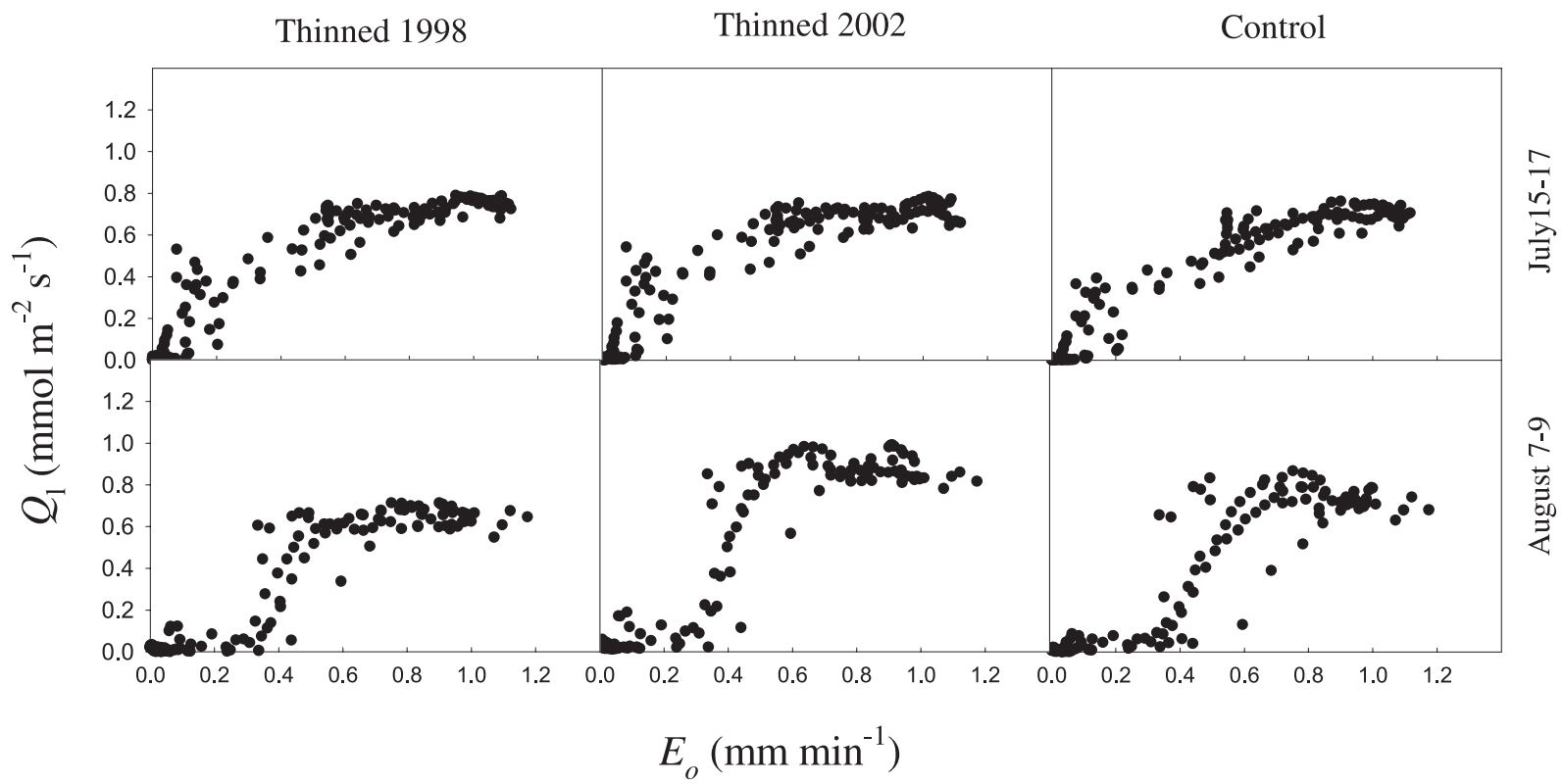

Figure 3. Mean transpiration per unit leaf area $\left(Q_{1}\right)$ vs. potential evaporation $\left(E_{0}\right)$ for 10 min intervals during two three-day periods of high evaporative demand.

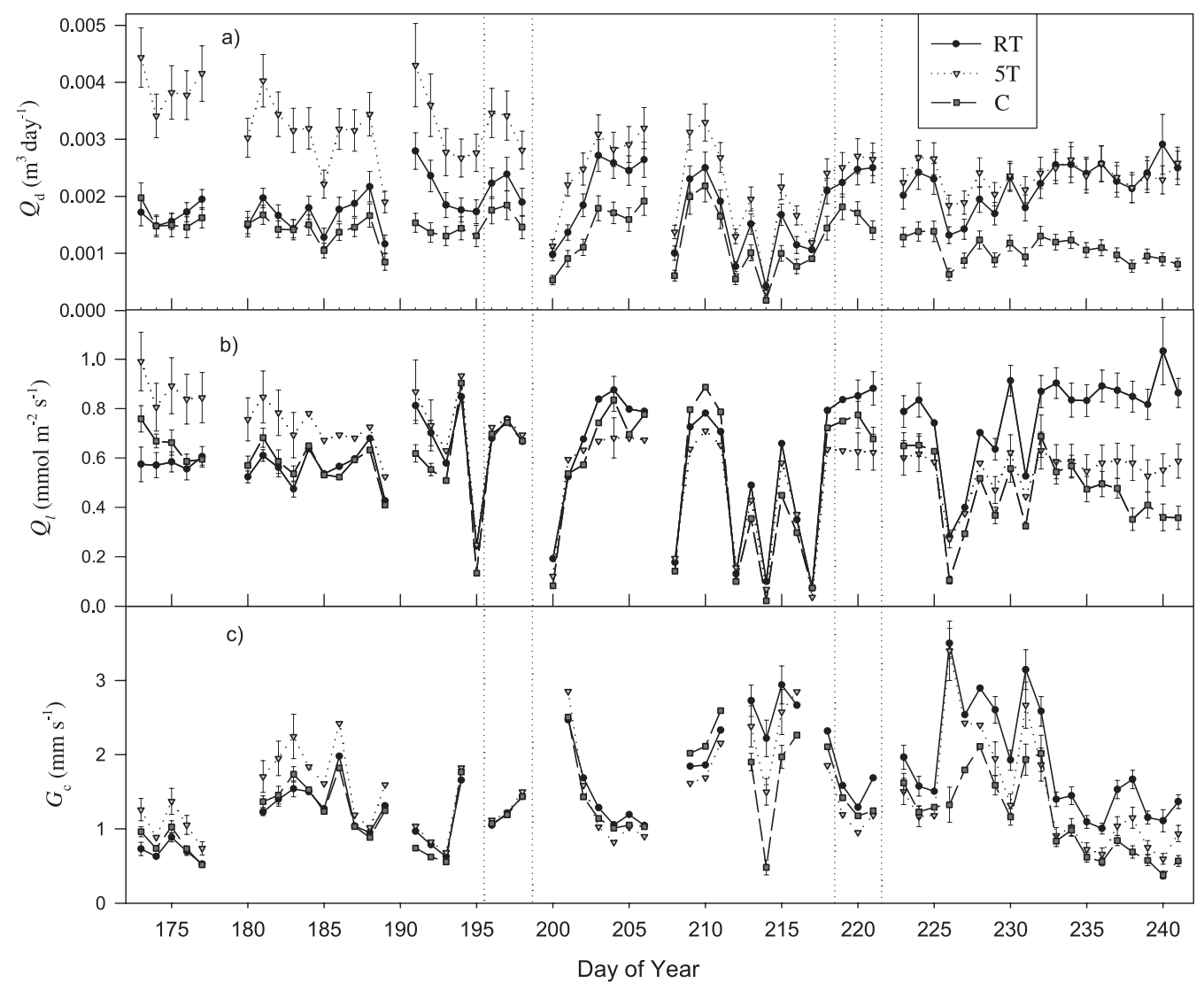

Figure 4. Daily means for (a) total sap flow $\left(Q_{\mathrm{d}}\right)$, (b) mid-day transpiration per unit leaf area $\left(Q_{1}\right)$, and (c) mid-day whole canopy average stomatal conductance $\left(G_{\mathrm{c}}\right)$ of recently thinned $(\mathrm{RT})$, thinned 5 years prior $(5 \mathrm{~T})$ and control $(\mathrm{C})$ trees. Error bars represent one standard error, and are only presented where at least one does not overlap either of the other two. Dashed vertical lines indicate the two three-day periods presented in Figure 3. 
Table I. Mean height (Ht), diameter at breast height (dbh), crown length (CL), leader length (LL), leaf area $\left(A_{\mathrm{L}}\right)$, sapwood basal area $\left(A_{\mathrm{s}}\right.$, sapwood permeability $(\mathrm{k})$, hydraulic capacity $\left(Q_{\mathrm{h}}\right)$, and leaf specific hydraulic capacity $\left(Q_{\mathrm{L}}\right)$ recorded at the conclusion of the measurement period ( \pm standard error) and test statistics from ANOVA for trees thinned in 1998 (5T), trees thinned in 2002 (RT), and un-thinned controls (C).

\begin{tabular}{|c|c|c|c|c|c|}
\hline & $5 T(n=11)$ & $R T(n=11)$ & $C(n=10)$ & $F$ & $p$ \\
\hline $\mathrm{Ht}(\mathrm{m})$ & $4.8 \pm 0.21$ & $5.2 \pm 0.15$ & $5.3 \pm 0.15$ & 2.9 & 0.07 \\
\hline $\mathrm{dbh}(\mathrm{cm})$ & $6.6 \pm 0.3$ & $5.7 \pm 1.3$ & $5.4 \pm 0.2$ & 6.5 & 0.004 \\
\hline CL (m) & $3.7 \pm 0.2$ & $3.6 \pm 0.2$ & $3.7 \pm 0.1$ & $\mathrm{n} / \mathrm{s} 0.17$ & $\mathrm{n} / \mathrm{s} 0.84$ \\
\hline $\operatorname{LL}(\mathrm{cm})$ & $25.9 \pm 3.2$ & $38.1 \pm 1.9$ & $43.8 \pm 1.7$ & 15.5 & $<0.001$ \\
\hline$A_{\mathrm{L}}\left(\mathrm{m}^{2}\right)$ & $5.9 \pm 0.7$ & $3.7 \pm 0.3$ & $3.2 \pm 0.4$ & 12.2 & 0.0001 \\
\hline$A_{s}\left(\mathrm{~cm}^{2}\right)$ & $28.3 \pm 2.7$ & $21.3 \pm 1.1$ & $19.4 \pm 1.5$ & 6.2 & 0.006 \\
\hline$S\left(\mathrm{~m}^{2} \mathrm{~cm}^{-2}\right)$ & $0.22 \pm 0.02$ & $0.17 \pm 0.01$ & $0.16 \pm 0.01$ & 4.4 & 0.02 \\
\hline$K_{\Psi}\left(\times 10^{-12} \mathrm{~m}^{2} \mathrm{~Pa}^{-1} \mathrm{~s}^{-1}\right)$ & $1.97 \pm 0.10$ & $2.10 \pm 0.10$ & $2.47 \pm 0.11$ & 6.2 & 0.006 \\
\hline$Q_{\mathrm{h}}\left(\times 10^{-12} \mathrm{~m}^{4} \mathrm{~Pa}^{-1} \mathrm{~s}^{-1}\right)$ & $5.44 \pm 0.72$ & $3.72 \pm 0.26$ & $4.07 \pm 0.35$ & 3.48 & 0.04 \\
\hline$Q_{L}\left(\times 10^{-12} \mathrm{~m}^{2} \mathrm{~Pa}^{-1} \mathrm{~s}^{-1}\right)$ & $0.93 \pm 0.10$ & $1.02 \pm 0.06$ & $1.33 \pm 0.07$ & 6.16 & 0.006 \\
\hline $\mathrm{LAI}^{*}\left(\mathrm{~m}^{2} \mathrm{~m}^{-2}\right)$ & 2.1 & 1.7 & $>5$ & & \\
\hline
\end{tabular}

* LAIs presented are for lodgepole pine trees only based on stand density and measured $A_{\mathrm{L}}$. We assumed $A_{\mathrm{L}}=2 \mathrm{~m}^{2}$ tree ${ }^{-1}$ in the C stand to account for the lower leaf area of sub-dominant trees.

trees (Fig. 4c). Despite considerable day-to-day variability, $G_{\mathrm{c}}$ was generally consistent among treatments during much of the summer (Fig. 4c).

Measurements of tree characteristics made at the end of the summer (Tab. I) were consistent with those previously reported by Liu et al. [20] including significantly larger leaf area, and reduced sapwood permeability $(k)$ in $5 \mathrm{~T}$ trees. In addition, differences in sapwood hydraulic characteristics associated with the new thinning treatment were apparent within one growing season. Sapwood permeability $(k)$ was $22 \%$ higher in $\mathrm{C}$ trees compared to RT and 5T trees combined, which did not differ among treatments at the 0.05 level (Tab. I). There was significant variation in hydraulic capacity $\left(Q_{\mathrm{h}}\right)$ between treatments ( $p=0.04$, Tab. I), but only RT (lowest) and 5T trees (highest) were significantly different. Despite lower $k, Q_{\mathrm{h}}$ of 5T and $\mathrm{C}$ trees was not significantly different due to the larger sapwood conducting area of the 5T trees. More importantly, due to the large leaf area maintained by $5 \mathrm{~T}$ trees, leaf specific hydraulic capacity $\left(Q_{\mathrm{L}}\right)$ was $43 \%$ lower than that of $\mathrm{C}$ trees. Similarly, significantly higher sapwood $k$, combined with nonsignificant differences in leaf area and sapwood area, resulted in C trees having a $Q_{\mathrm{L}}$ that was $30 \%$ greater than that of RT trees.

\section{DISCUSSION}

Our data indicates a dramatic increase in water use by lodgepole pine trees in thinned stands by the end of the first growing season following thinning. Over the summer of 2002, total daily water use $\left(Q_{\mathrm{d}}, \mathrm{m}^{3} \mathrm{day}^{-1}\right)$ of the RT trees increased to the level of the $5 \mathrm{~T}$ trees, more than double that of the $\mathrm{C}$ trees (Fig. 4a). There also appeared to be a gradual trend of declining daily water use $\left(Q_{\mathrm{d}}\right)$ with time for both the $5 \mathrm{~T}$ and $\mathrm{C}$ trees, perhaps as a result of buildup of drought conditions. The consistently higher $Q_{\mathrm{d}}$ we observed in $5 \mathrm{~T}$ relative to $\mathrm{C}$ trees was not simply due to their greater leaf area (Tab. I), as has been observed in Pinus radiata [40]; the 5T also had higher mean transpiration per unit of leaf area $\left(Q_{1}\right)$ over the measurement period. The striking increase in $Q_{\mathrm{d}}$ of RT trees was counter to our expectation of a decline due to hydraulic damage to stem sapwood associated with thinning [20], which was also apparent immediately following thinning in the current study (Tab. I). Greater $Q_{\mathrm{d}}$ of RT trees in August compared to June suggests their access to soil water had improved over time, despite well below normal precipitation. Lower LAI following thinning can reduce demand for water resulting in increased water availability in the rooting zone [24]. McDowell et al. (in review) have also shown that decadal thinning to maintain constant basal area provided sustained improvements in water availability to 84 year-old ponderosa pine trees. In addition, increased allocation to root growth in the year following pre-commercial thinning has been observed in other conifer species [36], and has been proposed as a mechanism by which Douglas fir and lodgepole pine trees meet increases in evaporative demand after release [16]. One or a combination of this two factors could explain how the RT trees were able to increase $Q_{\mathrm{d}}$ in such a short period. In the C stand, $Q_{\mathrm{d}}$ was consistently lower than in the thinned stands. This was likely due to the lower availability of soil water due to higher canopy interception of precipitation [1], and greater LAI and hence stand level water use of this stand. The highest $Q_{\mathrm{d}}$ value observed on June 30th in $5 \mathrm{~T}$ trees (Fig. 4a, Julian day 181) was likely due to a combination of factors. The 5T trees had nearly double the leaf area of RT and $\mathrm{C}$ trees. The warm conditions on this day resulted in the highest midday $Q^{*}$ and $E_{\mathrm{o}}$ recorded (Fig. 1). Further, soil moisture was likely high because of the carry over of moisture from snowmelt, supplemented by recent rains (Fig. 1).

Our most striking observation was the apparent hydraulic recovery of RT trees in less than 3 months. In June RT trees 
had the lowest transpiration per unit leaf area $\left(Q_{1}\right)$ and the lowest whole tree stomatal conductance $\left(G_{\mathrm{c}}\right)$ (Julian days 174 176; Figs. 4b and 4c), an indication of greater water stress relative to $5 \mathrm{~T}$ and $\mathrm{C}$ trees. Exposure of RT trees to increased radiant energy following thinning was likely to have resulted in lower leaf water potential [15], which is known to stimulate stomatal closure in lodgepole pine [2]; this is a possible explanation for the lower $Q_{1}$ and $G_{\mathrm{c}}$ we observed in June. Since thinning had occurred only one month prior, RT trees may not have acclimated to increased exposure to full sunlight, known to stimulate rapid opening of stomata [21], and increased evaporative demand due to higher wind speeds that occur in thinned lodgepole pine stands [34]. By August, however, the RT trees appeared to have recovered, consistently having higher $Q_{1}$ and $G_{\mathrm{c}}$ than both 5T and $\mathrm{C}$ trees on days when differences were apparent (Julian days 226-241; Figs. 4b and 4c). Whitehead's model (Eq. (8) in [43]) that links sapwood permeability to stomatal conductance suggests that, given the declines in $k$ we observed (Tab. I), RT and 5T trees would require a smaller water potential difference between roots and leaves and/or a decrease in air saturation deficit at the evaporating surface relative to $\mathrm{C}$ trees to explain increased $G_{\mathrm{c}}$. Since a decrease in air saturation deficit is unlikely as wind speeds increase in thinned stands [35], a smaller difference in water potential is the most plausible explanation. Within individual trees adjustments in $G_{\mathrm{c}}$ can occur rapidly in response to changes in the leaf area to sapwood area ratio [44]. Thinning reduces stand level sapwood area, and the retained trees at this site responded by increasing leaf area over the last five years. Nevertheless, Whitehead's [43] model suggests that despite increased $S$ in the $5 \mathrm{~T}$ trees, $G_{\mathrm{c}}$ should remain high relative to $\mathrm{C}$ trees until they have grown sufficiently so that stand level leaf area is again in balance with site water availability. This hypothesis requires careful examination of the differences in leaf and soil water potential between thinned and un-thinned stands to be properly tested.

Day to day variation in $G_{\mathrm{c}}$ appeared to be closely linked to vapour pressure deficit, and precipitation during the dry summer of 2002. All three stands likely experienced similar levels of water stress from the apparent covariance of $G_{\mathrm{c}}$ among treatments through July (Julian days 182-212). Days when $G_{\mathrm{c}}$ increased across treatments were generally associated with low $(D)$ and/or precipitation events (Fig. 1). There was one day when $G_{\mathrm{c}}$ of trees in the thinned stands (5T and RT) increased dramatically from the previous day relative to $\mathrm{C}$ trees (August 14, Julian day 226; Fig. 4c). This observation coincided with low $D(0.18 \mathrm{kPa})$, a reasonably high $Q^{*}\left(372.9 \mathrm{~W} \mathrm{~m}^{-2}\right)$, and a large overnight rain event (Fig. 1), suggesting trees in the thinned stands were better able to take advantage of increased water availability in the rooting zone. Observations of improved soil water access following thinning in lodgepole pine stands [5], and the close link between stomatal behavior and soil water availability in ponderosa pine experiencing periodic drought stress [26] support our suggestion that $G_{\mathrm{c}}$ was closely linked to soil water availability.

Stored water in stem sapwood likely had little influence on sap flow in the relatively small stems we examined because lags between increasing $E_{\mathrm{o}}$ and $v_{\mathrm{s}}$ that can be attributed to use of stored water $[29,31]$ were infrequently observed. A rapid increase in $Q_{1}$ associated with increasing $E_{\mathrm{o}}$ in the morning (Fig. 3 top row) was the usual pattern observed. Lags between $Q_{1}$ and $E_{\mathrm{o}}$, when observed (Fig. 3 bottom row), were likely a result of the canopy being at least partially de-coupled from the atmosphere during the early morning due to the accumulation of dew on the foliage. For several hours each night on August 7-9 (DOY 219-221), and during the nights prior to days when lags were apparent (July 23, DOY 205; August 22, DOY 234 data not shown) $D$ was at the dew point. No lags were observed on $96 \%$ of the days when data were collected, on days without dew. Assuming that our midday observations of $Q_{1}$ were unaffected by dew, the consistent leveling-off of $Q_{1}$ with increasing $E_{\mathrm{o}}$ (Fig. 3) suggests stomatal behavior had a strong influence on transpiration during clear days.

Declines in sapwood permeability $(k)$ previously associated with thinning on this site [20] did not appear to limit the supply of water to crowns of the lodgepole pine trees that were retained. The declines in $k$ we observed were unlikely to have been due to damage caused by bending as wind speeds were generally light $\left(\right.$ mean $\left.=1.2 \mathrm{~m} \mathrm{~s}^{-1}, \max .=2.9 \mathrm{~m} \mathrm{~s}^{-1}\right)$, and chronic bending stress over 5 years does not affect $k$ in lodgepole pine (Meng et al. unpublished). Rainfall was only $27 \%$ of the long term normal (1971-2000, Environment Canada) for May and June, and among the Pinaceae, the genus Pinus is particularly vulnerable to development of embolism under water stress [22]. This would suggest that the declines in $k$ we observed by the end of the summer were more likely to have been due to cavitation and subsequent development of embolism during hot dry weather. The lower $Q_{1}$ and $G_{\mathrm{c}}$ of RT trees compared to $5 \mathrm{~T}$ and $\mathrm{C}$ trees in June (Fig. 4b) indicate that RT trees likely experienced water stress and/or reduced $k$ immediately following thinning.

Our data from lodgepole pine provides some evidence that contradicts the suggestion that there is a tight balance between leaf area and stem hydraulic capacity $\left(Q_{\mathrm{h}}\right)$ [41]. Despite having lower hydraulic capacity per unit leaf area, 5T trees were able to maintain double the leaf area of un-thinned controls. For the 5T trees, increases in radial growth compensated for declines in $k$, resulting in the highest $Q_{\mathrm{h}}$ among the three treatments. The trees from the $5 \mathrm{~T}$ treatment also had lower height growth compared to adjacent $\mathrm{C}$ and RT trees (Tab. I). Allocation to radial growth at the expense of height growth may allow lodgepole pine to maintain $Q_{\mathrm{h}}$ despite a propensity for development of embolism under water stress. Lodgepole pine trees can maintain 23-30 years investment in sapwood area [32], perhaps as a mechanism to facilitate survival during periodic droughts. In contrast to the suggestion that $Q_{\mathrm{h}}$ and leaf area are tightly coupled, our observations suggest that lodgepole pine maintains sufficient stem sapwood to survive the loss of some $Q_{\mathrm{h}}$ during drought. Despite apparent damage to water conducting tissues associated with thinning (lower $Q_{\mathrm{L}}$; Tab. I), availability of water to leaves in 5T and RT trees did not appear to be limited. It is unclear if the apparent increase in $Q_{1}$ observed in RT trees from June to August was associated with repair of suspected embolism [13], or greater soil water access through root growth. Reduced $Q_{\mathrm{L}}$ did not, however, appear to limit flow during the measurement period since transpiration 
rates of residual thinned trees were consistently higher than the controls.

Acknowledgements: This research was made possible by joint funding provided by NSERC, Weldwood of Canada, and Weyerhaeuser Company. West Fraser Mills Ltd. through the Enhanced Forest Management Scholarship also provided funding to D.E.B. Reid. Thanks to Brendan Brabender, Kevin Bladon, Bryn Jonzon, Wei Liu, and Brent Frey for field assistance, and Pak Chow for laboratory contributions.

\section{REFERENCES}

[1] Aussenac G., Granier A., Effects of thinning on water-stress and growth in Douglas-fir, Can. J. For. Res. 18 (1988) 100-105.

[2] Bassman J.H., Koch P., Physiology, in: P. Koch (Ed.), Lodgepole Pine in North America, Forest Products Society, Madison, Wisconsin, 1996, pp. 77-137.

[3] Breda N., Granier A., Aussenac G., Effects of thinning on soil and tree water relations, transpiration and growth in an oak forest (Quercus petraea (Matt) Liebl), Tree Physiol. 15 (1995) 295-306.

[4] Day R.J., The ancient and orderly European discipline of thinning is now a reality in North America, in: Bamsey C. (Ed.), Stand Density Management: Planning and Implementation, Proceedings of a conference held November 6 and 7 in Edmonton, Alberta, Canada, Clear Lake Ltd., Edmonton, AB, 1998, pp. 24-33.

[5] Donner B.L., Running S.W., Water stress response after thinning Pinus contorta stands in Montana, For. Sci. 32 (1986) 614-625.

[6] Dingman S.L., Physical hydrology, 2nd Ed., Prentice Hall, Englewood Cliffs, N.J. (2002).

[7] Edwards W.R.N., Becker P., and Čermák J., A unified nomenclature for sap flow measurements, Tree Physiol. 17 (1997) 65-67.

[8] Farnden C., Herring L., Severely repressed lodgepole pine responds to thinning and fertilization: 19-year results, For. Chron. 78 (2002) 404-414.

[9] Flesch T.K., Wilson J.D., Extreme value analysis of wind gusts in Alberta. Forestry Canada and Alberta Land and Forestry Services, University of Alberta, Edmonton, Alta, Can.-Alta, Partnership Agree, For. Proj. A-8033-107.

[10] Giambelluca T.W., Nullet D., Evaporation at high elevations in Hawaii, J. Hydrol. 136 (1992) 219-235

[11] Granier A., Une nouvelle méthode pour la mesure du flux de sève brute dans le tronc des arbres, Ann. Sci. For. 42 (1985) 193-200.

[12] Granier A., Evaluation of transpiration in a Douglas-fir stand by means of sap flow measurements, Tree Physiol. 3 (1987) 309-319.

[13] Holbrook N.M., Zwieniecki M.A., Embolism repair and xylem tension: Do we need a miracle? Plant Physiol. 120 (1999) 7-10.

[14] Huang S., Monserud R.A., Braun T., Lougheed H., Bakowsky O., Comparing site productivity of mature fire-origin and post-harvest juvenile lodgepole pine stands in Alberta, Can. J. For. Res. 34 (2004) 1181-1191.

[15] Jarvis P.G., Water transfer in plants, in: Heat and Mass Transfer in the Plant Environment, Part 1, Scripta Book Co., Washington DC, 1975, pp. 369-394.

[16] Kneeshaw D., Williams H., Nikinmaa E., Messier C., Patterns of above- and below-ground response of understory conifer release 6 years after partial cutting, Can. J. For. Res. 32 (2002) 255-265.

[17] Köstner B., Biron P., Siegwolf R., Granier A., Estimates of water vapor flux and canopy conductance of Scots pine at the tree level utilizing different xylem sap flow methods, Theor. Appl. Climatol. 53 (1996) 105-113.
[18] Lagergren F., Lindroth A., Variation in sapflow and stem growth in relation to tree size, competition and thinning in a mixed forest of pine and spruce in Sweden, For. Ecol. Manage. 188 (2004) 51-63.

[19] Linacre E.T., Net radiation to various surfaces, J. App. Ecol. 6 (1969) 61-75.

[20] Liu X.D., Silins U., Lieffers V.J., Man R.Z., Stem hydraulic properties and growth in lodgepole pine stands following thinning and sway treatment, Can. J. For. Res. 33 (2003) 1295-1303.

[21] Lopushinsky W., Water relations and photosynthesis in Lodgepole pine, in: Baumgartner D.M. (Ed.), Management of Lodgepole Pine Ecosystems, Symposium proceedings, Pullman, Washington October 9-11, Washington State University Cooperative Extension Service, 1973, pp. 135-153.

[22] Martínez-Vilalta J., Sala A., Piñol J., The hydraulic architecture of Pinaceae - a review, Plant Ecol. 171 (2004) 3-13.

[23] Martínez-Vilalta J., Mangiron M., Ogaya R., Sauret M., Serrano L., Penuelas J., Pinol J., Sap flow of three co-occurring Mediterranean woody species under varying atmospheric and soil water conditions, Tree Physiol. 23 (2003) 747-758.

[24] McDowell N.G., Brooks J.R., Fitzgerald S., Bond B.J., Carbon isotope discrimination and growth response of old Pinus ponderosa trees to stand density reductions, Plant Cell Environ. 26 (2003) 631644.

[25] Medhurst J.L., Battaglia M., Beadle C.L., Measured and predicted changes in tree and stand water use following high-intensity thinning of an 8-year-old Eucalyptus nitens plantation, Tree Physiol. 22 (2002) 775-784.

[26] Misson L., Panek J.A., Goldstein A.H., A comparison of three approaches to modeling leaf gas exchange in annually droughtstressed ponderosa pine forests, Tree Physiol. 24 (2004) 529-541.

[27] Monteith J.L., Evaporation and environment, in: The State and Movement of Water in Living Organisms, 8-12 September 1964 Swansea, Symp. Soc. Exp. Biol., 1965, vol. 19, pp. 205-234.

[28] Morikawa Y., Hattori S., Kiyono Y., Transpiration of a 31-year-old Chamaecyparis obtusa Endl. stand before and after thinning, Tree Physiology 2 (1986) 105-114.

[29] Phillips N.G., Ryan M.G., Bond B.J., Mcdowell N.G., Hinckley T.M., Čermák J., Reliance on stored water increases with tree size in three species in the Pacific Northwest, Tree Physiol. 23 (2003) 237-245.

[30] Phillips N., Oren R., A comparison of daily representations of canopy conductance based on two conditional time-averaging methods and the dependence of daily conductance on environmental factors, Ann. Sci. For. 55 (1998) 217-235.

[31] Phillips N., Nagchaudhuri A., Oren R., Katul G., Time constant for water transport in loblolly pine trees estimated from time series of evaporative demand and stem sapflow, Trees-Struct. Funct. 11 (1997) 412-419.

[32] Reid D.E.B., Silins U., Lieffers V.J., Stem sapwood permeability in relation to crown dominance and site quality in self-thinning fireorigin lodgepole pine stands, Tree Physiol. 23 (2003) 833-840.

[33] Reid D.E.B., Silins U., Mendoza C., Lieffers V.J., A unified nomenclature for quantification and description of water conducting properties of sapwood xylem based on Darcy's law, Tree Physiol. 25 (2005) 993-1000.

[34] Rudnicki M., Group tree sway of lodgepole pine, associated crown interactions and their potential role in mediating crown shyness, Ph.D. thesis, University of Alberta, Edmonton, Alta, 2002.

[35] Rudnicki M., Lieffers V.J., Silins U., Stand structure governs the crown collisions of lodgepole pine, Can. J. For. Res. 33 (2003) $1238-1244$

[36] Ruel J.C., Larouche C., Achim A., Changes in root morphology after precommercial thinning in balsam fir stands, Can. J. For. Res. 33 (2003) 2452-2459. 
[37] Simpson D.G., Water use of interior Douglas-fir, Can. J. For. Res. 30 (2000) 534-547.

[38] Stewart J.B., The albedo of a pine forest, Q. J. R. Meteorol. Soc. 99 (1971) 561-564.

[39] Strong W.L., Leggat K.R., Ecoregions of Alberta. Alberta Forestry, Land and Wildlife, Land Information Services Division, Resource Information Branch, Edmonton, Alta, 1992.

[40] Teskey R.O., Sheriff D.W., Water use by Pinus radiata trees in a plantation, Tree Physiol. 16 (1996) 273-279.

[41] Tyree M.T., Sperry J.S., Do woody plants operate near the point of catastrophic xylem dysfunction caused by dynamic water stress? Answers from a model, Plant Physiol. 88 (1988) 574-580.

[42] Vertessy R.A., Benyon R.G., O’Sullivan S.K., Gribben P.R., Relationships between stem diameter, sapwood area, leaf-area and transpiration in a young mountain ash forest, Tree Physiol. 15 (1995) 559-567.
[43] Whitehead D., Regulation of stomatal conductance and transpiration in forest canopies, Tree Physiol. 18 (1998) 633-644.

[44] Whitehead D., Livingston N.J., Kelliher F.M., Hogan K.P., Pepin S., McSeveny T.M., Byers J.N., Response of transpiration and photosynthesis to a transient change in illuminated foliage area for a Pinus radiata D. Don tree, Plant Cell Environ. 19 (1996) 949-957.

[45] Whitehead D., Jarvis P.G., Coniferous forests and plantations: water uptake and movement, in: Water Deficits and Plant Growth, Vol. 6, 1981, pp. 50-152.

[46] Worall J., Height growth stagnation in lodgepole pine: all (well almost all) is revealed, Branchlines 6 (1981) 5.

[47] Yang R.C., Foliage and stand growth responses of semi-mature lodgepole pine to thinning and fertilization, Can. J. For. Res. 28 (1998) 1794-1804.

[48] Youngblood A.P., Radial growth after a shelterwood cut in a mature stand of white spruce, Can. J. For. Res. 21 (1991) 410-413. 